\title{
Effect of Post-production Heat Treatment on Particleboard from Sugarcane Bagasse
}

\author{
Amélia Guimarães Carvalho ${ }^{a *}$, Rafael Farinassi Mendes ${ }^{b}$, \\ Stefânia Lima Oliveira ${ }^{b}$,Lourival Marin Mendes ${ }^{b}$ \\ ${ }^{a}$ Forestry Engineering Department, Federal University of Viçosa - UFV, CEP 36570-000, Viçosa, MG, Brazil \\ ${ }^{b}$ Federal University of Lavras - UFLA, CP 3037, CEP 37200-000, Lavras, MG, Brazil
}

Received: February 7, 2014; Revised: January 15, 2015

\begin{abstract}
This study aimed to evaluate the effect of heat treatment on the physical and mechanical properties of particleboard from sugarcane bagasse. The experiment consisted of seven treatments arranged in a $2 \times 3$ factorial arrangement (two heat treatment times -8 and $12 \mathrm{~min}$, and three heat treatment temperatures $-200{ }^{\circ} \mathrm{C}, 230{ }^{\circ} \mathrm{C}$, and $260{ }^{\circ} \mathrm{C}$ ) and treatment control (without heat treatment). We evaluated the properties such as apparent density, water absorption after 2 and $24 \mathrm{~h}$ (WA2h andWA24h), thickness swell after 2 and $24 \mathrm{~h}$ (TS2h and TS24h), irreversible thickness swelling rate (ITS), internal bond, Modulus of Elasticity (MOE), and Modulus of Rupture (MOR) in static bending. In general, the use of heat treatment appeared very promising for improving the dimensional stability of sugarcane bagasse particleboard, without being made unviable by the mechanical properties reduction.
\end{abstract}

Keywords: particleboard, sugarcane bagasse, heat treatment

\section{Introduction}

Particleboard industries consume a significant amount of wood from planted forests, mainly of Pinus and Eucalyptus genera. However, in principle, these panels can be produced from any lignocellulosic material that provides high mechanical strength and good physical characteristics ${ }^{1,2,3}$. Thus, the recovery of waste generated by the Brazilian agribusiness industry has become an alternative to meet the demand of the particleboard industry, which is exhibiting increased growth. The Brazilian agroindustry offers many types of lignocellulosic residues, which have potential for particleboards production such as corncob, rice husk, coffee hull, peanut hull, banana plant stem, coconut husk, cassava stem, castor bean hull, sugarcane bagasse, etc. ${ }^{3,4}$.

Among the agricultural waste, sugarcane bagasse stands out because Brazil is a world leader in the production of sugarcane, with a production of approximately 1.8 billion tons in $2011^{5}$, which represents the generation of about 500 million tons of sugarcane bagasse, because, according to Silva et al. ${ }^{6}$, each ton of processed cane sugar generates a total of $280 \mathrm{~kg}$ of waste.

Some studies on the use of bagasse for the production of particleboard have revealed its significant potential ${ }^{2,4,7,8,9,10}$. However, because of its low density, a large amount of bagasse particles is required to form the panel, causing an increase in the compressive stress at pressing time and a greater number of hygroscopic sites, thus making the panel more susceptible to water absorption and dimensional change.

Mendes et al. ${ }^{11}$ evaluated commercial sugarcane bagasse particleboard produced in China and found that

*e-mail: ameliagcarvalho@gmail.com these panels even present higher water absorption and thickness swelling values than panels produced on an industrial scale with eucalyptus and pine wood, which, depending on some types of use, may prove to be a problem, thus requiring viable alternatives to increase the range of uses of these panels.

One of the possible alternatives for improving the dimensional stability of the panels is heat treatment, which aims to degrade the hemicellulose, the more hygroscopic component of the cell wall, as well as free up the compressive stress formed during pressing ${ }^{12,13,14}$. The degradation of wood hemicelluloses, which starts below $200{ }^{\circ} \mathrm{C}$, begins with deacetylation, and the released acetic acid acts as a depolymerization catalyst that further increases polysaccharide decomposition ${ }^{15}$. Alén et al. ${ }^{16}$ observed that among the hemicelluloses, xylans could be degraded more easily. At higher temperatures $\left(230^{\circ} \mathrm{C}\right)$, the xylose and mannose contents in wood decrease, and arabinose and galactose disappear ${ }^{17}$, whereas between $250{ }^{\circ} \mathrm{C}$ and $330{ }^{\circ} \mathrm{C}$, total destruction of hemicelluloses usually occurs ${ }^{18}$.

Some studies have reported the influence of thermal treatment on the conventional particleboard-type wood panels, such as flakeboard, waferboard, MDF, and OSB, which have been proved promising, because, usually, heat treatment in already-consolidated panels provides improved dimensional stability and resistance to xylophage attack $^{13,19,20,21,22,23,24}$. However, heat treatment in panels can also promote reduction of their mechanical properties ${ }^{14,19,25}$. In this context, the present study aimed to evaluate the effect of heat treatment on the physical and mechanical properties of particleboard from sugarcane bagasse. 


\section{Material and Methods}

\subsection{Preparation of material}

Commercial sugarcane bagasse particleboards, produced in China with urea-formaldehyde adhesive, were used. These panels were divided into smaller panels with dimensions of $50 \times 50 \mathrm{~cm}$, which were conditioned in a room at a temperature of $22 \pm 2{ }^{\circ} \mathrm{C}$ and relative humidity of $65 \pm 5 \%$.

\subsection{Thermal treatment}

After climatization, the panels were heat treated in a hydraulic press under controlled time, temperature, and pressure. The tests performed are specified in Table 1. For each treatment, there were three replicates.

The pressure used for the heat treatment was $0.5 \mathrm{kgf} /$ $\mathrm{cm}^{2}$ to promote good contact between the press platens and the panel to facilitate temperature conduction. A duration of $10 \mathrm{~s}$ was employed for closing the press, the press was kept closed for 8 or $12 \mathrm{~min}$ according to each treatment, and a subsequent 10-s duration was allowed to open the press.

\subsection{Physical and mechanical properties}

The test bodies were obtained by using a standard saw. The dimensions of the test bodies and test procedures used for the evaluation of the properties of apparent density, water absorption after 2 and $24 \mathrm{~h}$ (WA2h and WA24h), thickness swell after 2- and 24-h immersion (TS2h and TS24h), irreversible thickness swelling rate (ITS), and internal bond (IB) were according to the determinations of the ASTM D $1037^{26}$ norm, while for the properties of the modulus of elasticity (MOE) and modulus of rupture (MOR) in static bending, the DIN $52362^{27}$ norm was adopted.

\subsection{Evaluation of the results}

For statistical analysis of the data, the experiment was conducted in completely randomized design, in which the treatments were arranged in a $2 \times 3$ factorial arrangement (two treatment times -8 and $12 \mathrm{~min}$, and three heat treatment temperatures $-200{ }^{\circ} \mathrm{C}, 230^{\circ} \mathrm{C}$, and $260{ }^{\circ} \mathrm{C}$ ) and a control (no treatment). For comparison between the panels that had undergone some treatment and the control panels, Dunnett's test at 5\% significance was conducted. The Tukey test, also at $5 \%$ significance, was performed for the properties that showed significant interaction between the temperature and heat treatment time as well as for evaluating the apparent density and thickness of the panels.

Table 1. Description of thermal treatment.

\begin{tabular}{ccc}
\hline Treatment & Temperature $\left({ }^{\circ} \mathbf{C}\right)$ & Time (minutes) \\
\hline Control & - & - \\
T1 & 200 & 8 \\
T2 & & 12 \\
T3 & 230 & 8 \\
T4 & & 12 \\
T5 & 260 & 8 \\
T6 & & 12 \\
\hline
\end{tabular}

\section{Results and Discussion}

\subsection{Apparent density and thickness of the panels}

Only the heat treatment performed in the particleboard at $260^{\circ} \mathrm{C}$ for $12 \mathrm{~min}$ promoted a significant panel density reduction. With regard to the thickness of the panels as well as apparent density, only the panels treated at $260{ }^{\circ} \mathrm{C}$ for 12 min showed significant difference, when compared with the control panels, achieving greater average thickness (Table 2). Taking into account that the increase in the thickness results in an increase in the volume of the panel and that the panel density is given by the ratio between mass and volume, it is possible that the panel density reduction with thermal treatment resulted mainly in the function of the increase in their thickness. This thickness increase is the result of partial release of the compressive stress, which occurred shortly after the end of pressing in the production phase of the pane $1^{13}$. Another aspect related to the decrease in the apparent density of the panels may be related to chemical degradation of some wood polymers, especially polyoses ${ }^{25}$.

Del Menezzi and Tomaselli20 applied heat treatment at $250{ }^{\circ} \mathrm{C}$ for 4,7 , and $10 \mathrm{~min}$ to OSB panels and with the increase in treatment duration, the panel lost more mass, and finally, its density was reduced. Mendes et al. ${ }^{13}$ on studying the effect of heat treatment on strand particles at $200-240{ }^{\circ} \mathrm{C}$ with respect to the quality of OSB panels, observed a significant reduction in the density of the panels, with the reductions being $4 \%$ and $7 \%$, respectively. The authors also observed a direct effect of the panel thickness increase on their decreased density.

\subsection{Physical properties}

Table 3 presents the average water absorption values after $2 \mathrm{~h}$ (WA2h) and $24 \mathrm{~h}$ (WA24h) for each of the treatments, as well as the variation in the average values of the heat-treated panels in relation to the control panels.

By comparing the results of the Dunnett test, it can be observed that all the panels that underwent heat treatment differed statistically from the control treatment, achieving lowest values of WA2 $\mathrm{h}$ and WA24h. The reduction of WA2h and WA24h was in the order of $27.7 \%-61.8 \%$ and $29.5 \%$ $53.5 \%$, respectively. Tjeerdsma and Militz $^{28}$ stated that the decrease in hygroscopicity was owing to the reduction in the accessibility of free hydroxyl groups (sorption sites)

Table 2. Apparent density and thickness of sugarcane bagasse particleboard.

\begin{tabular}{ccc}
\hline Treatment & $\begin{array}{c}\text { Apparent density } \\
\left(\mathbf{g} / \mathbf{c m}^{3}\right)\end{array}$ & $\begin{array}{c}\text { Thickness } \\
(\mathbf{m m})\end{array}$ \\
\hline Control & $0.61^{(0.01)} \mathrm{a}^{*}$ & $14.9^{(0.11)} \mathrm{a}$ \\
$200^{\circ} \mathrm{C} / 8 \mathrm{~min}$ & $0.60^{(0.03)} \mathrm{a}$ & $15.0^{(0.07)} \mathrm{a}$ \\
$200^{\circ} \mathrm{C} / 12 \mathrm{~min}$ & $0.61^{(0.01)} \mathrm{a}$ & $15.0^{(0.09)} \mathrm{a}$ \\
$230^{\circ} \mathrm{C} / 8 \mathrm{~min}$ & $0.59^{(0.01)} \mathrm{ab}$ & $15.1^{(0.06)} \mathrm{a}$ \\
$230^{\circ} \mathrm{C} / 12 \mathrm{~min}$ & $0.59^{(0.01)} \mathrm{ab}$ & $15.2^{(0.06)} \mathrm{ab}$ \\
$260^{\circ} \mathrm{C} / 8 \mathrm{~min}$ & $0.58^{(0.01)} \mathrm{ab}$ & $15.2^{(0.10)} \mathrm{ab}$ \\
$260^{\circ} \mathrm{C} / 12 \mathrm{~min}$ & $0.56^{(0.02)} \mathrm{b}$ & $15.3^{(0.05)} \mathrm{b}$ \\
\hline *Means with same letter do not differ statistically by the Tukey test
\end{tabular}

*Means with same letter do not differ statistically by the Tukey test $(\mathrm{a}=0.05)$. The standard deviation is shown in parentheses. 
Table 3. Water absorption of cane bagasse particleboard.

\begin{tabular}{|c|c|c|c|c|}
\hline \multirow{3}{*}{ Treatment } & \multicolumn{4}{|c|}{ Water absorption (WA) } \\
\hline & $2 \mathrm{hs}$ & $\Delta$ & 24hs & $\Delta$ \\
\hline & \multicolumn{4}{|c|}{$\%$} \\
\hline $200^{\circ} \mathrm{C} / 8 \mathrm{~min}$ & $12.5^{(2.80) * *}$ & -27.7 & $37.6^{(5.42) * *}$ & -29.5 \\
\hline $200^{\circ} \mathrm{C} / 12 \mathrm{~min}$ & $9.8^{(0.67) * *}$ & -43.4 & $30.1^{(2.10) * *}$ & -43.5 \\
\hline $230^{\circ} \mathrm{C} / 8 \mathrm{~min}$ & $10.7^{(1.71) * *}$ & -38.2 & $32.6^{(4.36) * *}$ & -38.8 \\
\hline $230^{\circ} \mathrm{C} / 12 \mathrm{~min}$ & $6.7^{(0.83) * *}$ & -61.3 & $27.3^{(2.42)} * *$ & -48.8 \\
\hline $260^{\circ} \mathrm{C} / 8 \mathrm{~min}$ & $7.7^{(1.30) * *}$ & -55.5 & $26.8^{(1.31) * *}$ & -49.7 \\
\hline $260^{\circ} \mathrm{C} / 12 \mathrm{~min}$ & $6.6^{(1.61) * *}$ & -61.8 & $24.8^{(1.36) * *}$ & -53.5 \\
\hline Control & $17.3^{(3.59)}$ & & $53.3^{(3.36)}$ & \\
\hline
\end{tabular}

** Differ statistically from the control treatment by the Dunnett Test $(\alpha=0.01)$.

and formation of furfural polymers, which are the result of sugar degradation (hemicelluloses) and are less hygroscopic.

Winandy \& Krzysik ${ }^{22}$ thermally treated MDF panels at $180{ }^{\circ} \mathrm{C}, 200{ }^{\circ} \mathrm{C}$, and $220^{\circ} \mathrm{C}$ and detected reduction in arabinan and galactan, both of which are hemicellulose side-chain components. Mannan, which is a key component of the hemicellulose backbone, was also affected, but to a lesser extent. According to the authors, these changes in the hemicellulose seemed to reduce the hygroscopicity of the fibers. This in turn inhibited moisture sorption, which eventually led to water absorption, thickness swelling, and influenced loss of additional mechanical properties.

In the present study, data analysis revealed no interaction between the three temperatures $\left(200^{\circ} \mathrm{C}, 230^{\circ} \mathrm{C}\right.$, and $\left.260^{\circ} \mathrm{C}\right)$ and two time periods used ( 8 and $12 \mathrm{~min}$ ) with respect to WA2h and WA24h properties. Table 4 shows the average values of water absorption as a function of temperature.

According to Table 4, the treatment at $260^{\circ} \mathrm{C}$ showed the lowest WA2h and WA24h values, which were statistically equal in both the properties at the processing temperature of $230^{\circ} \mathrm{C}$. There was also no significant difference between the treatments at $200{ }^{\circ} \mathrm{C}$ and $230{ }^{\circ} \mathrm{C}$.

Table 5 shows the mean water absorption values as a function of thermal treatment time. It could be noted that the longer the heat treatment (12 min) was, the lowest the WA2 $\mathrm{h}$ and WA24h values were, which differed statistically from panels heat treated for $8 \mathrm{~min}$.

Mendes et al. ${ }^{3}$ evaluated the production of particleboard from bagasse in association with pine wood and the adhesive urea-formaldehyde and obtained WA2h values ranging from $32.1 \%$ to $54.1 \%$ and WA24h values ranging from $49.8 \%$ to $64.2 \%$. Furthermore, Mendes et al. ${ }^{10}$ evaluated different types of agricultural and forest residues for particleboard manufacturing and observed WA24h and WA2h values of $12.6 \%$ and $60.6 \%$, respectively, for the panels produced with cane bagasse. In general, the results obtained in the present study are below the values found in the literature for particleboard produced from sugarcane bagasse.

Table 6 shows the mean thickness swelling values after 2 and $24 \mathrm{~h}$ of immersion (TS2h and TS24h) and ITS for each of the treatments. The variation in the mean values of the heat-treated panels in relation to the control panels is also shown.

By comparing the Dunnett test for TS2h, only the treatment at $260{ }^{\circ} \mathrm{C}$ for $12 \mathrm{~min}$ of exposure differed
Table 4. Mean values of water absorption as a function of temperature.

\begin{tabular}{ccc}
\hline \multirow{2}{*}{ Temperature $\left({ }^{\circ} \mathbf{C}\right)$} & WA2h & WA24h \\
\cline { 2 - 3 } & \multicolumn{3}{c}{$\mathbf{\%}$} \\
\hline 200 & $11.2^{(2.41)} \mathrm{a}^{*}$ & $33.9^{(5.51)} \mathrm{a}$ \\
230 & $8.7^{(2.41)} \mathrm{ab}$ & $30.0^{(4.35)} \mathrm{ab}$ \\
260 & $7.1^{(1.49)} \mathrm{b}$ & $25.8^{(1.65)} \mathrm{b}$ \\
\hline
\end{tabular}

*Means with same letter do not differ statistically by the Tukey's test $(\mathrm{a}=0.05)$. Inside the parentheses is the standard deviation.

Table 5. Mean values of water absorption as a function of time.

\begin{tabular}{ccc}
\hline \multirow{2}{*}{ Time (min.) } & WA2h & WA24h \\
\cline { 2 - 3 } & \multicolumn{3}{c}{$\%$} \\
\hline 8 & $10.3^{(2.81)} \mathrm{a}^{*}$ & $32.3^{(5.93)} \mathrm{a}$ \\
12 & $7.7^{(1.83)} \mathrm{b}$ & $27.4^{(2.93)} \mathrm{b}$ \\
\hline
\end{tabular}

*Means with same letter do not differ statistically by the Tukey's test $(\mathrm{a}=0.05)$

significantly from the control panels, thereby reducing the amount of swelling by $26.6 \%$. This fact was associated with increased release of compressive stress obtained by these panels (Table 2). For TS24h and ITS, only treatments at $260{ }^{\circ} \mathrm{C}$ for both the durations ( 8 and $12 \mathrm{~min}$.) showed significant improvement, when compared with the panels without thermal treatment. The reductions ranged from $29.6 \%$ to $47.0 \%$ for TS $24 \mathrm{~h}$ and from $31.9 \%$ to $55.3 \%$ for the ITS.

According to the results of the analysis of variance, the interaction was observed between the three temperatures $\left(200{ }^{\circ} \mathrm{C}, 230^{\circ} \mathrm{C}\right.$, and $260^{\circ} \mathrm{C}$ ) and two treatment times ( 8 and $12 \mathrm{~min}$ ) for the properties of thickness swelling after 2 and $24 \mathrm{~h}$ of immersion and ITS. The results presented for the unfolding analysis are shown in Table 7.

In the heat treatment time analysis within each temperature evaluated, it can be seen that there was a significant effect of pressing time on the three properties (TS2h, TS24h, and ITS) at a temperature of only $260{ }^{\circ} \mathrm{C}$. The duration of $12 \mathrm{~min}$ presented the lowest values.

In the analysis of the temperature measured in each heat treatment time, it can be seen that for TS2h, the differentiation was observed only for the duration of $12 \mathrm{~min}$ at $260{ }^{\circ} \mathrm{C}$, which exhibited the lowest mean value and 
Table 6. Panel thickness swelling and irreversible thickness swell rate.

\begin{tabular}{|c|c|c|c|c|c|c|}
\hline \multirow{3}{*}{ Treatment } & \multicolumn{4}{|c|}{ Thickness swelling (TS) } & \multirow{2}{*}{\multicolumn{2}{|c|}{ ITS $\Delta$}} \\
\hline & $2 \mathrm{hs}$ & $\Delta$ & $24 \mathrm{hs}$ & $\Delta$ & & \\
\hline & \multicolumn{4}{|c|}{$\%$} & \multicolumn{2}{|c|}{$\%$} \\
\hline $200^{\circ} \mathrm{C} / 8 \mathrm{~min}$ & $5.9^{(0.72)} \mathrm{ns}$ & 11.3 & $13.1^{(0.42)} \mathrm{ns}$ & 13.9 & $5.1^{(0.62)} \mathrm{ns}$ & 8.5 \\
\hline $200^{\circ} \mathrm{C} / 12 \mathrm{~min}$ & $5.8^{(0.51)} \mathrm{ns}$ & 10.1 & $12.0^{(0.37)} \mathrm{ns}$ & 4.3 & $4.6^{(0.60)} \mathrm{ns}$ & -2.1 \\
\hline $230^{\circ} \mathrm{C} / 8 \mathrm{~min}$ & $4.9^{(0.68)} \mathrm{ns}$ & -7.5 & $9.8^{(0.59)} \mathrm{ns}$ & -14.8 & $3.6^{(0.53)} \mathrm{ns}$ & -23.4 \\
\hline $230^{\circ} \mathrm{C} / 12 \mathrm{~min}$ & $5.8^{(0.37)} \mathrm{ns}$ & 9.4 & $10.3^{(0.65)} \mathrm{ns}$ & -10.4 & $4.7^{(0.31)} \mathrm{ns}$ & 0.0 \\
\hline $260^{\circ} \mathrm{C} / 8 \mathrm{~min}$ & $5.3^{(0.48)} \mathrm{ns}$ & 0.0 & $8.0^{(0.90) * *}$ & -29.6 & $3.2^{(0.60)} *$ & -31.9 \\
\hline $260^{\circ} \mathrm{C} / 12 \mathrm{~min}$ & $3.9^{(0.58) * *}$ & -26.6 & $6.1^{(0.81) * *}$ & -47.0 & $2.1^{(0.46) *}$ & -55.3 \\
\hline Control & $5.3^{(0.44)}$ & & $11.5^{(0.78)}$ & & $4.7^{(0.55)}$ & \\
\hline
\end{tabular}

** Statistically differ from the control treatment by Dunnett's test $(\alpha=0.01)$. Statistically differ from the control treatment by Dunnett's test $(\alpha=0.05)$. ns does differ from the control treatment by Dunnett's test $(\alpha=0.01)$.

Table 7. Unfolding of interactions for the physical properties TS and ITS.

\begin{tabular}{|c|c|c|c|c|c|c|}
\hline \multirow{3}{*}{$\begin{array}{c}\text { Temperature } \\
\left({ }^{\circ} \mathrm{C}\right)\end{array}$} & \multicolumn{2}{|c|}{ TS 2h (\%) } & \multicolumn{2}{|c|}{ TS 24h (\%) } & \multicolumn{2}{|c|}{ ITS (\%) } \\
\hline & \multicolumn{6}{|c|}{ Tempo } \\
\hline & 8 & $12^{\prime}$ & 8 & $12^{\prime}$ & $8^{\prime}$ & 12 ' \\
\hline 200 & $5.9^{(0.72)} \mathrm{aA}^{*}$ & $5.8^{(0.51)} \mathrm{aA}$ & $13.1^{(0.42)} \mathrm{aA}$ & $12.0^{(0.37)} \mathrm{aA}$ & $5.1^{(0.62)} \mathrm{aA}$ & $4.6^{(0.60)} \mathrm{aA}$ \\
\hline 230 & $4.9^{(0.68)} \mathrm{aA}$ & $5.8^{(0.37)} \mathrm{aA}$ & $9.8^{(0.59)} \mathrm{bA}$ & $10.3^{(0.65)} \mathrm{bA}$ & $4.7^{(0.53)} \mathrm{aA}$ & $4.6^{(0.31)} \mathrm{aA}$ \\
\hline 260 & $5.3^{(0.48)} \mathrm{aA}$ & $3.9^{(0.58)} \mathrm{bB}$ & $8.0^{(0.90)} \mathrm{cA}$ & $6.1^{(0.81)} \mathrm{cB}$ & $3.2^{(0.60)} \mathrm{bA}$ & $2.1^{(0.46)} \mathrm{bB}$ \\
\hline
\end{tabular}

*Means with same letter do not differ statistically by the Tukey test $(\mathrm{a}=0.05)$. Lowercase letters refer to values in columns and uppercase to values on the lines.

statistically differed from other treatments. There was no statistical difference between the temperatures of $200{ }^{\circ} \mathrm{C}$ and $230^{\circ} \mathrm{C}$ at $12 \mathrm{~min}$. For TS24h, statistical difference was observed among all temperatures and at both evaluation times. As the heat treatment temperature increased, the mean values of TS24h decreased. For ITS, there was a statistical difference in both heat treatment times only at $260^{\circ} \mathrm{C}$, with lowest mean values. There was no statistical difference between $200{ }^{\circ} \mathrm{C}$ and $230{ }^{\circ} \mathrm{C}$ when the ITS property was evaluated.

These lower values of thickness swelling and ITS are associated with the release of compressive stress before the panels come into contact with moisture, which prevents thickness swelling and thus causes a decrease in ITS ${ }^{13}$. Del Menezzi19 attributed the compressive stress release mechanism to the viscoelastic behavior of wood, mainly lignin, which, with increasing temperature applied to the panel, causes the matrix formed by the wood polymers to present lower resistance to deformation, allowing the internal stress to be released or minimized by a rearrangement of the matrix. Basturk ${ }^{29}$, on evaluating the thermal treatment associated with chitosan treatment on the physical and mechanical properties of particleboard produced from Acer pseudoplatanus wood, observed a reduction of $23 \%$ and $28 \%$ for TS2h and TS24h, respectively, when the treated panels were compared with the control panels. Xiangquan et al. ${ }^{30}$ evaluated the heat post-treatment of particleboard produced with wood of the genus Populus at $190{ }^{\circ} \mathrm{C}$ for $5,10,15,20$, and $25 \mathrm{~min}$, and at $220{ }^{\circ} \mathrm{C}$ for 5 and $10 \mathrm{~min}$. Similar to that observed in the present study, both time and temperature were effective for the reduction of TS and ITS, with reductions being observed from $14.9 \%$ to $25.0 \%$ for TS $24 \mathrm{~h}$ and from $20.4 \%$ and $37.9 \%$ for ITS. Mendes et al. ${ }^{2}$ evaluated the quality of particleboard produced with the combination of sugarcane bagasse with eucalyptus wood, and observed values ranging from $5.8 \%$ to $10.9 \%$ for TS $2 \mathrm{~h}$ and from $12.0 \%$ to $22.7 \%$ for TS $24 \mathrm{~h}$. The ANSI A208.1 norm ${ }^{31}$ has stipulated a maximum of $8 \%$ for thickness swelling after $24 \mathrm{~h}$ of immersion in water. In this sense, the results obtained in the present work are inferior to those found in the literature. However, with regard to the marketing standard, only panels treated at $260^{\circ} \mathrm{C}$, regardless of the temperature exposure time, met the maximum value determined, thus demonstrating the need for the use of heat treatment for bagasse panels.

\subsection{Mechanical properties}

The mean values of MOE and MOR in static bending and the IB are shown in Table 8 . In addition, the variations in the mean values of the heat-treated panels in relation to the control panels are also shown.

According to the data given in Table 8 , it can be seen that the panels thermally treated at $200{ }^{\circ} \mathrm{C}$ for 8 and $12 \mathrm{~min}$ did not present significant difference in any of the mechanical properties evaluation, when compared with the control panels. The panels treated at $230{ }^{\circ} \mathrm{C}$ for 8 min showed no significant difference, when compared with the control panels only with respect to MOE and IB properties. The panels treated at $260{ }^{\circ} \mathrm{C}$ for 8 min showed no statistical difference only with respect to the IB property; however, with regard to the other properties, a reduction in the mean values was noted, when compared with the control panels. The panels treated at $260{ }^{\circ} \mathrm{C}$ for 12 min exhibited the most pronounced effect, causing reductions of $12.2 \%, 37.8 \%$, and $49.8 \%$ in MOE, MOR, and IB properties, respectively.

In general, chemical modifications and alterations of the wood resulting from heat treatment lead to alterations in the mechanical properties, reducing their average values ${ }^{19,25,32,33}$. 
In the present study, another factor that may have affected the mechanical properties could be the reduced density of the panels (Table 2), because a positive linear relationship exists between the density of the panels and their mechanical properties $^{34,35}$. According to the results of the analysis of variance, an interaction was observed between the three temperatures $\left(200{ }^{\circ} \mathrm{C}, 230{ }^{\circ} \mathrm{C}\right.$, and $\left.260{ }^{\circ} \mathrm{C}\right)$ and the two heat treatment times ( 8 and $12 \mathrm{~min}$ ) for MOE and MOR to static bending. The results of the unfolding analysis are shown in Table 9.

In the interaction between temperature and heat treatment time, it can be noted that in the analysis of each temperature, there was no significant effect of heat treatment time on the property MOE. With regard to MOR, there was a significant effect only at $230^{\circ} \mathrm{C}$, and the panels treated for a longer period of time (12 min) had the lowest mean value.

On analyzing the effect of temperature on each heat treatment time, we observed that for the time duration of 8 min, only MOR was affected, with the panels thermally treated at $260{ }^{\circ} \mathrm{C}$ showing the lowest mean value, differing statistically from those treated at $200^{\circ} \mathrm{C}$ and $230{ }^{\circ} \mathrm{C}$. For the time duration of $12 \mathrm{~min}, \mathrm{MOE}$ and $\mathrm{MOR}$ showed statistical difference, with panels thermally treated at $230{ }^{\circ} \mathrm{C}$ and $260{ }^{\circ} \mathrm{C}$ exhibiting similarity and statistically significant difference, respectively, in both the cases, when compared with those treated at $200{ }^{\circ} \mathrm{C}$, which presented the highest mean values of MOR and MOE in static bending.

The unfolding analysis revealed that, in general, the temperature level had a more pronounced effect on MOE and MOR in static bending than the thermal treatment time. This finding is similar to that observed by Del Menezzi ${ }^{19}$, who studied the effect of heat post-treatment at $190^{\circ}-220^{\circ} \mathrm{C}$ for 12, 16, and $20 \mathrm{~min}$ on the properties of OSB panels manufactured with the wood of Pinus sp.

In the present study, there was no interaction between the temperatures and times used in the thermal treatment with respect to the IB property of the panels. Table 10 presents the mean IBs as a function of temperature, which confirms that the IB values were not significantly altered at different temperatures.

Table 11 shows the mean IB values as a function of heat treatment time. It is possible to observe that the heat treatment time of 12 min caused a significant reduction in the IB of the panels, when compared with the heat treatment time of $8 \mathrm{~min}$.

Talavera et al. ${ }^{36}$ evaluated different production variables on the quality of the panels produced from bagasse in association with plastic waste and $10 \%$ urea-formaldehyde adhesive, and obtained values from 1069.0 to $1492.0 \mathrm{MPa}$ for MOE and 10.2 to 20.0 MPa for MOR. Mendes et al. ${ }^{2}$ evaluated the quality of particleboard produced from a combination of sugarcane bagasse with eucalyptus wood, and observed values ranging from 913.5 to $1063.2 \mathrm{MPa}$ for MOE, 1.7-15.0 MPa for MOR, and 0.34-0.85 MPa for IB. Barros Filho et al. ${ }^{9}$ assessed the quality of homogeneous panels produced from bagasse and urea-formaldehyde and melamine-urea-formaldehyde adhesives, and obtained MOE values ranging from 765.9 to $1129.0 \mathrm{MPa}$, MOR values ranging between 4.6 and $5.9 \mathrm{MPa}$, and IB from 0.17 to 0.55 $\mathrm{MPa}$. For M1 and M2 classes, the ANSI A208.1 norm ${ }^{31}$ has stipulated minimum values of 1726.0 and $1902.5 \mathrm{MPa}$ for MOE, 11.2 and 12.8 MPa for MOR, and 0.39 MPa for IB, respectively.

In the present study, the cane bagasse particleboard, even after heat treatment, presented mechanical properties

Table 8. Mechanical properties of particleboard from cane bagasse.

\begin{tabular}{|c|c|c|c|c|c|c|}
\hline \multirow{2}{*}{ Treatment } & MOE & $\Delta$ & MOR & $\Delta$ & IB & $\Delta$ \\
\hline & Мра & $\%$ & $\mathrm{MPa}$ & $\%$ & MPa & $\%$ \\
\hline $200^{\circ} \mathrm{C} / 8 \mathrm{~min}$ & $2289.3^{(190.75)} \mathrm{ns}$ & -8.2 & $16.2^{(1.72)} \mathrm{ns}$ & -5.8 & $0.31^{(0.06)} \mathrm{ns}$ & -24.4 \\
\hline $200^{\circ} \mathrm{C} / 12 \mathrm{~min}$ & $2428.9^{(133.46)} \mathrm{ns}$ & -2.6 & $16.0^{(1.35)} \mathrm{ns}$ & -7.0 & $0.30^{(0.03)} \mathrm{ns}$ & -26.8 \\
\hline $230^{\circ} \mathrm{C} / 8 \mathrm{~min}$ & $2325.0^{(258.09)} \mathrm{ns}$ & -6.7 & $14.5^{(2.66) * *}$ & -15.7 & $0.29^{(0.06)} \mathrm{ns}$ & -29.3 \\
\hline $230^{\circ} \mathrm{C} / 12 \mathrm{~min}$ & $2182.3^{(188.03)} * *$ & -12.5 & $11.3^{(1.26) * *}$ & -34.3 & $0.18^{(0.03)} * *$ & -56.1 \\
\hline $260^{\circ} \mathrm{C} / 8 \mathrm{~min}$ & $2203.3^{(164.38) * *}$ & -11.6 & $13.2^{(1.65) * *}$ & -23.3 & $0.29^{(0.13)} \mathrm{ns}$ & -29.3 \\
\hline $260^{\circ} \mathrm{C} / 12 \mathrm{~min}$ & $2189.8^{(89.95) * *}$ & -12.2 & $12.9^{(0.58) * *}$ & -25.0 & $0.21^{(0.05) * *}$ & -48.8 \\
\hline Control & $2493.2^{(299.02)}$ & & $17.2^{(3.01)}$ & & $0.41^{(0.04)}$ & \\
\hline
\end{tabular}

** Differ statistically from the control treatment by the Dunnett test $(\alpha=0.01)$. ns Does not differ statistically from the control treatment by the Dunnett test $(\alpha=0.01)$.

Table 9. Unfolding of interactions for the mechanical properties.

\begin{tabular}{|c|c|c|c|c|}
\hline \multirow{4}{*}{ Temperature $\left({ }^{\circ} \mathrm{C}\right)$} & \multicolumn{2}{|c|}{ MOE } & \multicolumn{2}{|c|}{ MOR } \\
\hline & \multicolumn{4}{|c|}{ MPa } \\
\hline & \multicolumn{4}{|c|}{ Time } \\
\hline & $8^{\prime}$ & 12 & $8^{\prime}$ & 12 \\
\hline 200 & $2289.3^{(190.75)} \mathrm{aA}^{*}$ & $2428.9^{(133.46)} \mathrm{aA}$ & $16.2^{(1.72)} \mathrm{aA}$ & $16.0^{(1.35)} \mathrm{aA}$ \\
\hline 230 & $2325.0^{(258.09)} \mathrm{aA}$ & $2182.3^{(188.03)} \mathrm{bA}$ & $14.5^{(2.66)} \mathrm{aA}$ & $11.3^{(1.26)} \mathrm{bB}$ \\
\hline 260 & $2203.3^{(164.38)} \mathrm{aA}$ & $2189.8^{(89.95)} \mathrm{bA}$ & $13.2^{(1.65)} \mathrm{bA}$ & $12.9^{(0.58)} \mathrm{bA}$ \\
\hline
\end{tabular}

*Means with same letter do not differ statistically by the Tukey test $(\mathrm{a}=0.05)$. Lowercase letters refer to values in columns and uppercase to values on the lines. 
Table 10. Average values of internal bond as a function of temperature.

\begin{tabular}{cc}
\hline Temperature $\left({ }^{\circ} \mathbf{C}\right)$ & IB $(\mathbf{M P a})$ \\
\hline 200 & $0.31^{(0.04)} \mathrm{a}^{*}$ \\
230 & $0.24^{(0.07)} \mathrm{a}$ \\
260 & $0.25^{(0.10)} \mathrm{a}$ \\
\hline
\end{tabular}

*Means with same letter do not differ statistically by the Tukey test $(\mathrm{a}=0.05)$.

Table 11. Average values of internal bond as a function of time.

\begin{tabular}{cl}
\hline Time (min.) & IB (MPa) \\
\hline 8 & $0.30^{(0.08)} \mathrm{a}^{*}$ \\
12 & $0.23^{(0.06)} \mathrm{b}$ \\
\hline
\end{tabular}

*Means with same letter do not differ statistically by the Tukey test $(\mathrm{a}=0.05)$.

consistent with or even higher than those found in the literature. When compared with the ANSI A208.131 marketing standard, all the treatments met the requirements for class M2, the most demanding property for MOE. For MOR, only the panels heat treated at $230{ }^{\circ} \mathrm{C}$ for $12 \mathrm{~min}$ did not meet the marketing standard requirement for class M2, but were able to meet the requirement for class M1. With regard to the IB property, only the control treatment met the requirements of the standard.

These low IB values, regardless of the heat treatment, have also been observed in several studies on bagasse panels $^{3,9,10}$, which is basically owing to the low density of the bagasse material and the consequent need to increase the number of particles to form a panel of predetermined density. This causes an increase in the surface area for the same amount of adhesive, thus more markedly promoting the decrease in the IB property.

\section{References}

1. Rowell RM, Han JS and Rowell JS. Characterization and factors affecting fiber properties. In: Frollini E, Leão AL and Mattoso LHC, editors. Natural polymers and agrofibers based composites. Section II: agrofibers composites. São Carlos: Embrapa Instrumentação Agropecuária; 2000. p. 115-134.

2. Mendes RF, Mendes LM, Abranches RAS, Santos RCS and Guimarães Júnior JB. Painéis aglomerados produzidos com bagaço de cana em associação com madeira de eucalipto. Scientia Forestalis. 2010; 38(86):285-295.

3. Mendes RF, Guimarães Junior JB, Santos RC and César AAS. Efeito da associação de bagaço de cana, tipo e teor de adesivo na produção de painéis aglomerados com madeira de pinus. Ciência Florestal. 2012; 22:187-196.

4. Mendes RF, Guimarães Junior JB, Santos RC and Bufalino L. The adhesive effect on the properties of particleboards made from sugar cane generated in the distiller. Revista de Ciências Agrárias. 2009; 32(2):209-218.

5. Food and Agriculture Organization of the United Nations FAOSTAT. Rome. Available from: <http://faostat.fao.org/ site/567/DesktopDefault.aspx?PageID=567\#ancor $>$. Access in: $07 / 02 / 2013$.

\section{Conclusions}

Only heat treatment conducted at $260^{\circ} \mathrm{C}$ for a period of 12 min promoted significant reductions in all the properties evaluated. However, the heat treatment applied at $260{ }^{\circ} \mathrm{C}$, regardless of the exposure time, allowed the bagasse panels to achieve the maximum TS24h value stipulated by the ANSI A208. $1^{31}$ marketing standard. The panels heat treated at $230^{\circ} \mathrm{C}$ and $260^{\circ} \mathrm{C}$ showed significant reductions in the values of MOR and MOE in static bending. However, all the treatments met the minimum requirement stipulated by ANSI A208. $1^{31}$.

The heat treatment affected the IB property to the point that all the heat-treated panels did not meet the commercialization standard. The level of heat treatment temperature showed more pronounced effect on the physical and mechanical properties of particleboard obtained from bagasse than the exposure time. In general, the use of heat treatment was shown to be very promising for improving the dimensional stability of cane bagasse particleboard, without being made unviable by the reduction in mechanical properties.

This technique of heat treatment could be integrated into a manufacturing process by allowing a longer period of time in the press (continuous press), or after acclimatization of the panels in a press with multiple dishes. However, although the technique can improve the quality (physical and against fungi) of the panels, it would result in higher cost and increase the production time, if done at the time of pressing the panel.

\section{Acknowledgments}

The authors thank the Universidade Federal de Lavras (UFLA) for supporting the experimental work and Conselho Nacional de Desenvolvimento Científico e Tecnológico (CNPq) and Fundação de Amparo à Pesquisa do estado de Minas Gerais (FAPEMIG) for the financial support.

6. Silva VLMM, Gomes WCO and Alsina LS. Utilização do bagaço de cana de açúcar como biomassa adsorvente na adsorção de poluentes orgânicos. Revista Eletrônica de Materiais e Processos. 2007; 2:27-32.

7. Widyorini R, Xu J, Umemura K and Kawai S. Manufacture and properties of binderless particleboard from bagasse I: Effects of raw material type, storage methods, and manufacturing process. Journal of Wood Science. 2005; 51(6):648-654. http://dx.doi. org/10.1007/s10086-005-0713-z.

8. Xu X, Yao F, Wu Q and Zhou D. The influence of wax-sizing on dimension stability and mechanical properties of bagasse particleboard. Industrial Crops and Products. 2009; 29(1):8085. http://dx.doi.org/10.1016/j.indcrop.2008.04.008.

9. Barros Filho RM, Mendes LM, Novack KM, Aprelini LO and Botaro VR. Hybrid chipboard panels based on sugarcane bagasse, urea formaldehyde and melamine formaldehyde resin. Industrial Crops and Products. 2011; 33(2):369-373. http:// dx.doi.org/10.1016/j.indcrop.2010.11.007.

10. Mendes RF, Mendes LM, Tonoli GHD, Bufalino L, Mori FA and Guimarães Júnior JB. Lignocellulosic composites made from agricultural and forestry wastes in Brazil. Key Engineering Materials. 2012; 517:556-563. http://dx.doi. org/10.4028/www.scientific.net/KEM.517.556. 
11. Mendes RF, Mendes LM, Guimarães Junior JB and Mendonça LL. Qualidade de painéis aglomerados produzidos na china utilizando bagaço de cana. In: Anais do XI Encontro Brasileiro em Madeiras e Estruturas de Madeira - EBRAMEM; 2008; Londrina, PR. Londrina: Editora UEL; 2008. p. 1-9. v. 1, n. 1.

12. Del Menezzi CHS, Tomaselli I, Okino EYA, Teixeira DE and Santana MAE. Thermal modification of consolidated oriented strand boards: effects on dimensional stability, mechanical properties, chemical composition and surface color. European Journal of Wood and Wood Products. 2009; 67(4):383-396.

13. Mendes RF, Bortoletto Júnior G, Almeida NF, Surdi PG and Barbeiro IN. Effect of thermal treatment on properties of OSB panels. Wood Science and Technology. 2013; 47(2):243-256. http://dx.doi.org/10.1007/s00226-012-0494-7.

14. Mendes RF, Bortoletto Júnior G, Almeida NF, Surdi PG and Barbeiro IN. Effects of thermal pre-treatment and variables of production on properties of OSB panels of Pinus taeda. Maderas. Ciencia y Tecnología. 2013; 15(2):141-152.

15. Nuopponen M, Vuorinen T, Jamsä S and Viitaniemi P. Thermal modifications in softwood studied by FT-IR and UV resonance Raman spectroscopies. Journal of Wood Chemistry and Technology. 2005; 24(1):13-26. http://dx.doi.org/10.1081/ WCT-120035941.

16. Alén R, Kotilainen R and Zaman A. Thermochemical behavior of Norway spruce (Picea abies) at $180-225^{\circ} \mathrm{C}$. Wood Science and Technology. 2002; 36(2):163-171. http://dx.doi. org/10.1007/s00226-001-0133-1.

17. Jämsä $S$ and Viitaniemi P. Heat treatment of wood: better durability without chemicals. In: Rapp Hamburg AO, editor. Proceedings of special seminar held in Antibes. France: BFH; 2001.

18. Brito JO, Silva FG, Leão MM and Almeida G. Chemical composition changes in eucalyptus and pinus woods submitted to heat treatment. Bioresource Technology. 2008; 99(18):85458548. http://dx.doi.org/10.1016/j.biortech.2008.03.069. PMid: 18586488

19. Del Menezzi CHS. Estabilização dimensional por meio do tratamento térmico e seus efeitos sobre as propriedades de painéis de partículas orientadas (OSB). [Tese em Ciências Agrárias]. Paraná: Universidade Federal do Paraná; 2004. 242 p. $</$ ths $>$.

20. Del Menezzi CHS and Tomaselli I. Contact thermal posttreatment of oriented strandboard to improve dimensional stability: a preliminary study. Holz als Roh- und Werkstoff. 2006; 64(3):212-217. http://dx.doi.org/10.1007/s00107-0050052-1.

21. Okino EYA, Teixeira DE and Del Menezzi CHS. Post-thermal treatment of oriented strandboard (OSB) made from Cypress (Cupressus glauca Lam.). Maderas: Ciencia y Tecnologia. 2007; 9(3):199-210.

22. Winandy JE and Krzysik AM. Thermal degradation of wood fibers during hot pressing of MDF composites: Part I. Relative effects and benefits of thermal exposure. Wood and Fiber Science. 2007; 39(3):450-461.
23. Del Menezzi CHS, Souza RQ, Thompson RM, Teixeira DE, Okino EYA and Costa AF. Properties after weathering and decay resistance of a thermally modified wood structural board. International Biodeterioration \& Biodegradation. 2008; 62(4):448-454. http://dx.doi.org/10.1016/j.ibiod.2007.11.010.

24. Lára Santos AM, Souza F, Costa MA, Teles RF, Pazetto VMF and Del Menezzi CHS. Efeito do tratamento térmico sobre a resistência ao cisalhamento da linha de cola em painéis OSB. Ciência Florestal. 2009; 19(1):31-40.

25. Paul W, Ohlmeyer $M$ and Leithoff $H$. Thermal modification of OSB-strands by a one-step heat pre-treatment - Influence of temperature on weight loss. hygroscopicity and improved fungal resistance. Holz als Roh- und Werkstoff. 2007; 65(1):5763. http://dx.doi.org/10.1007/s00107-006-0146-4.

26. American Society for Testing and Material - ASTM. D103706A: test methods for evaluating properties of wood-base fiber and particle panel materials. West Conshohocken; 2006.

27. Deutsches Institut Für Normung. DIN 52362: testing of wood chipboards, bending test, determination of bending strength. Germany; 1982. p. 39-40

28. Tjeerdsma BF and Militz H. Chemical changes in hydrothermal treated wood: FTIR analysis of combined hydrothermal and dry heat-treated wood. European Journal of Wood and Wood Products. 2005; 63(2):102-111. http://dx.doi.org/10.1007/ s00107-004-0532-8.

29. Basturk MA. Heat applied chitosan treatment on hardwood chips to improve physical and mechanical properties of particleboard. BioResources. 2012; 7(4):4858-4866. http:// dx.doi.org/10.15376/biores.7.4.4858-4866.

30. Xiangquan Z, Renshu L, Weihong W and Anbin P. Heat PostTreatment to Reduce Thickness Swelling of Particleboard from Fast-Growing Poplars. Journal of Forest Research. 1997; 8(3):188-190. http://dx.doi.org/10.1007/BF02855417.

31. American National Standards Institute - ANSI. ANSI A208: mat-formed wood particleboard: specification. Gaithersburg: National Particleboard Association; 1993.

32. Santos JA. Mechanical behaviour of eucalyptus wood modified by heat. Wood Science and Technology. 2000; 34(1):39-43. http://dx.doi.org/10.1007/s002260050006.

33. Kubojima Y, Okano T and Ohta M. Bending strength and toughness of heat-treated wood. Wood Science and Technology. 2000; 46(1):8-15. http://dx.doi.org/10.1007/BF00779547.

34. Maloney TM. Modern particleboard and dry-process fiberboard manufacturing. San Francisco: M. Freeman; 1993. $689 \mathrm{p}$.

35. Iwakiri S, Stinghen ABM, Silveira EL, Zamarian EHC, Prata JG and Bronoski M. Influência da massa específica sobre as propriedades mecânicas de painéis aglomerados. Floresta. 2008; 38(3):487-493. http://dx.doi.org/10.5380/rf.v38i3.12414.

36. Talavera FJF, Guzmán JAS, Richter HG, Dueñas RS and Quirarte JR. Effect of production variables on bending properties, water absorption and thickness swelling of bagasse/ plastic composite boards. Industrial Crops and Products. 2007; 26(1):1-7. http://dx.doi.org/10.1016/j.indcrop.2006.12.014. 